\title{
Pembelajaran Pendekatan Scientific Aproach yang Terintegrasi dalam Model Pebelajaran Berbasis Proyek (PBP) Sebagai Upaya PEncapaian KOmpetensi Ilmiah Mahasiswa Pada Program Studi Pend. Fisika FKIP UPR
}

\author{
Saulim DT. Hutahaean*, Nawir and Theo Jhoni Hartanto
}

\begin{abstract}
Ringkasan
Tujuan dari penelitian ini adalah untuk mengimplementasikan Pembelajaran Pendekatan Scientific Aproach yang Terintegrasi dalam MOdel Pembelajaran Berbasis Proyek (PBP) Sebagai Upaya Pencapaian Kompetensi Ilmiah Mahasiswa Pada Program Studi Pend. Fisika FKIP UPR. Secara rinci kompetensi yang di teliti adalah keterampilan mahasiswa dalam; (a) melakukan perencanaan, (b) melakukan perancangan, (c) melaksanakan penyelidikan, (d) melakukan pelaporan. Metode yang digunakan dalam penelitian ini adalah studi kasus dan desain penelitian praeksperimen dengan rancangan One Group Pretest-Posttest Design, dimana sampel penelitian ini adalah 48 orang mahasiswa prodi fisika yang sedang menempuh mata kuliah pengembangan program pengajaran fisika. Data kuantitatif diperoleh melalui tes kinerja dan tes kognitif yang kemudian dianalisis secara deskriptif. Hasil penelitian menunjukan bahwa implementasi Pembelajaran Pendekatan Scientific Aproach yang Terintegrasi dalam Model Pembelajaran BErbasis Proyek (PBP) membawa dampak pada penguasaan keterampilan mahasiswa dalam hal (a) melakukan perencanaan kategori cukup baik, (b) melakukan perancangan kategori baik, (c) melaksanakan penyelidikan kategori sangat baik, dan (d) melakukan pelaporan kategori baik.

Kata Kunci : pembelajaran pendekatan Scientific Aproach, pembelajaran berbasis proyek, kompetensi ilmiah

\section{Abstract}

The purpose of this study was to implement scientific approach learning in line with Project based learning to achieve students' scientific competention. The competence that we analyzed was student' skills on (a) planning, (b) designing, (c) investigating, (d) reporting the result of investigation. The current study used a one group pretest and posttest design. The sample of the study consist of $48^{\text {th }}$ students attending in the Physisc Education Program, University of Palangka Raya. The findings of the study revealed that the implementation of scientific approach learning in line with Project based learning have a good effect on students' skill which included the components of planning, designing, investigating, and reporting the investigation result.
\end{abstract}

Keywords: scientific approach; project based learning; scientific competention

\section{Pendahuluan}

Menurut teori yang diungkapkan oleh Piaget setiap individu dapat membangun sendiri skemanya dan membangun konsep-konsep melalui

\footnotetext{
${ }^{*}$ Correspondence: s.dapottua.h@gmail.com

Program Studi Pendidikan Fisika FKIP Universitas Palangkaraya, JI. Yos Sudarso Kampus UPR, Tanjung Nyaho, Palangkaraya, Indonesia

Full list of author information is available at the end of the article

${ }^{\dagger}$ Equal contributor
}

pengalaman-pengalamannya sendiri, dengan demikian pembelajaran yang dilakukan hendaknya diarahkan pada pemberian pengalaman-pengalaman bermakna yang dapat membangun konsep dan skema mahasiswa tersebut. Menurut Padiya (2008), model pembelajaran yang dapat mengajarkan mahasiswa untuk menguasai keterampilan proses dan penerapannya dalam kehidupan sehari-hari sehingga membuat pembelajaran menjadi bermakna adalah model 
Pembelajaran Berbasis Proyek (PBP) yang berfokus pada konsep-konsep dan prinsip-prinsip utama dari suatu disiplin ilmu. Dalam pelaksanaan PBP, mahasiswa dilibatkan dalam kegiatan pemecahan masalah dan tugas-tugas bermakna lainnya, memberi peluang kepada mahasiswa untuk bekerja secara otonom, mengkonstruk belajar mereka sendiri, dan pada akhirnya menghasilkan produk nyata yang bernilai, dan realistik.

Selanjutnya menurut Padiya (2008), PBP memiliki potensi yang besar untuk membuat pengalaman belajar yang menarik dan bermakna bagi pebelajar dewasa untuk memasuki lapangan kerja. Hal ini menunjukkan bahwa, dengan melibatkan mahasiswa calon guru dalam melakukan proyek penyelidikan ilmiah maka proses pembelajaran akan menjadi lebih bermakna karena mahasiswa diberikan kebebasan penuh dalam merencanakan, merancang serta melaksanakan suatu penyelidikan ilmiah dimana kegiatan-kegiatan tersebut masih berada dalam jangkauan pemikiran mereka.

Pada pelaksanaan PBP tidak hanya menekankan pada pemahaman mahasiswa terhadap prosedur metode ilmiah tetapi, mahasiswa diharapkan dapat melakukan perencanaan, perancangan dan pelaksanaan, serta pelaporan (Dediknas, 2004). Sejalan dengan itu Buck Institute of Education (1999) dalam Khamdi (2008), megungkapkan bahwa PBP memiliki karakteristik sebagai berikut: (a) mahasiswa melakukan perencanaan, dimana yang dilakukan mahasiswa pada tahap ini adalah membuat keputusan, dan membuat kerangka kerja, terhadap masalah yang pemecahannya tidak ditentukan sebelumnya, (b) mahasiswa melakukan perancangan, (c) mahasiswa melaksanakan penyelidikan, (d) mahasiswa melakukan pelaporan, dimana yang dilakukan mahasiswa pada tahap ini adalah melaporkan hasil akhir berupa produk yang telah dievaluasi kualitasnya, baik secara tertulis maupun secara lisan.

VanCleave (1997) mengungkapkan bahwa "A science project is an investigation using the scientific method to discover the answer to a scientific problem yang dapat diartikan bahwa proyek ilmiah merupakan suatu penyelidikan yang menggunakan langkah-langkah metode ilmiah untuk mengemukakan jawaban atas suatu masalah ilmiah. Berdasarkan pengertian tersebut maka yang menjadi syarat utama dalam melakukan proyek ilmiah adalah penguasaan keterampilan-keterampilan ilmiah. Mata kuliah Pengembangan Program Pengajaran Fisika (P3F) merupakan mata kuliah yang wajib diprogramkan oleh mahasiswa Jurusan Pendidikan MIPA Universitas Palangkaraya. Mengingat begitu pentingnya matakuliah ini bagi mahasiswa calon guru, maka sangat dipandang perlu melakukan berbagai cara dan upaya guna untuk pengembangan, penguatan pemahaman dan keterampilan mahasiswa khususnya dalam peningkatan kompetensi ilmiah mahasiswa itu sendiri. Dengan demikian, maka mahasiswa akan di pandang lebih cakap untuk menyelesaikan banyak masalah dalam kehidupan sehari-hari, dengan demikian masalah-masalah dalam kehidupan sehari-hari tersebut dapat dijadikan sebagai proyek penyelidikan ilmiah bagi mahasiswa.

\section{METODE PENELITIAN}

\subsection{Model Pembelajaran Berbasis Proyek}

Berdasarkan artikel yang dipublikasikan John Wiley \& Sons, Inc, (1997) dalam Khamdi (2008) mengungkapkan bahwa "A science project is an investigation using the scientific method to discover the answer to a scientific problem" yang dapat dimaknai bahwa, proyek ilmiah merupakan suatu penyelidikan yang menggunakan langkah-langakah metode ilmiah untuk memperoleh jawaban atas suatu masalah ilmiah. Demikian pula dalam pelaksanaan pembelajaran yang menggunakan pendekatan PBP mahasiswa diarahkan untuk melaksanakan suatu penyelidikan ilmiah yang berbentuk proyek dan dalam pelaksanaanya mahasiswa diharapkan dapat melakukan perencanaan, perancangan dan pelaksanaan, serta pelaporan hasil penyelidikan (Depdiknas, 2004).

Menurut Santyasa, implementasi pendekatan PBP terdiri dari tahapan seperti tabel 1 berikut:

Tabel 1. Tahapan Pembelajaran Berbasis Proyek

\begin{tabular}{|c|c|c|c|}
\hline No & Tahapan & Kegiatan guru/dosen & Kegiatan siswa/mahasiswa \\
\hline 1 & Perencanaan & $\begin{array}{l}\text { Guru menetapkan tema } \\
\text { proyek, menetapkan } \\
\text { konsep belajar } \\
\text { siswa/mahasiswa, dan } \\
\text { merencanakan aktifitas- } \\
\text { aktifitas yang haus } \\
\text { dilakukan siswa. }\end{array}$ & $\begin{array}{l}\text { Siswa/mahasiswa melakukan } \\
\text { aktifitas-aktifitas yang telah } \\
\text { direncanakan dan ditetapkan } \\
\text { oleh guru guna memperoleh } \\
\text { masalah dalam kehidupan } \\
\text { sehari-hari, terkait dengan tema } \\
\text { yang ditetapkan guru. }\end{array}$ \\
\hline 2 & Perancangan & $\begin{array}{l}\text { Guru memproses } \\
\text { aktifitas-aktifitas yang } \\
\text { dilakukan } \\
\text { siswa/mahasiswa. }\end{array}$ & $\begin{array}{l}\text { Siswa/mahasiswa membuat } \\
\text { sketsa, menetapkan teknik } \\
\text { analisis data dan } \\
\text { mengembangkan prototipe, } \\
\text { sebagai rancangan awal untuk } \\
\text { melakukan penelitian terhadap } \\
\text { masalah yang diperoleh. }\end{array}$ \\
\hline 3 & Pelaksanaan & $\begin{array}{l}\text { Mengawasi } \\
\text { siswa/mahasiswa dalam } \\
\text { penerapan aktifitas- } \\
\text { aktifitas untuk } \\
\text { meydesaikan proyok. }\end{array}$ & $\begin{array}{l}\text { Mencoba mengerjakan proyek } \\
\text { berdasarkan sketsa, menguji } \\
\text { langkah-langkah yang telah } \\
\text { dikerjakan dan hasil yang } \\
\text { diperoleh, mengevaluas hasil } \\
\text { yang telah diperoleh, merevisi } \\
\text { hasil yang telah diperoleh, } \\
\text { melakukan daur ulang proyek } \\
\text { yang lain, mengklasifikasi hasil } \\
\text { terbaik. }\end{array}$ \\
\hline 4 & Pelaporan & $\begin{array}{l}\text { Menilai laporan proyek } \\
\text { penyelidikan Imiah } \\
\text { yang dikerjakan oleh } \\
\text { siswa/mahasiswa baik } \\
\text { secara tertulis maupun } \\
\text { secara lisan. }\end{array}$ & $\begin{array}{l}\text { Menyusun laponan hasl } \\
\text { penyelidikan ilmiah secara } \\
\text { tertulis, dan } \\
\text { mempresentasekannya secara } \\
\text { lisan. }\end{array}$ \\
\hline
\end{tabular}




\subsection{Inkuiri Ilmiah}

Proses pembelajaran dapat dipadankan dengan suatu proses ilmiah. Pendekatan ilmiah diyakini sebagai titian emas perkembangan dan pengembangan sikap, keterampilan, dan pengetahuan peserta didik. Dalam pendekatan atau proses kerja yang memenuhi kriteria ilmiah, para ilmuan lebih mengedepankan pelararan induktif (inductive reasoning)ketimbang penalaran deduktif (deductivereasoning). Penalaran deduktif melihat fenomena umum untuk kemudian menarik simpulan yang spesifik. Sebaliknya, penalaran induktif memandang fenomena atau situasi spesifik untuk kemudian menarik simpulan secara keseluruhan. Sejatinya, penalaran induktif menempatkan bukti-bukti spesifik ke dalam relasi idea yang lebih luas. Metode ilmiah umumnya menempatkan fenomena unik dengan kajian spesifik dan detail untuk kemudian merumuskan simpulan umum.

A. Langkah-langkah Pembelajaran dengan Pendekatan Ilmiah

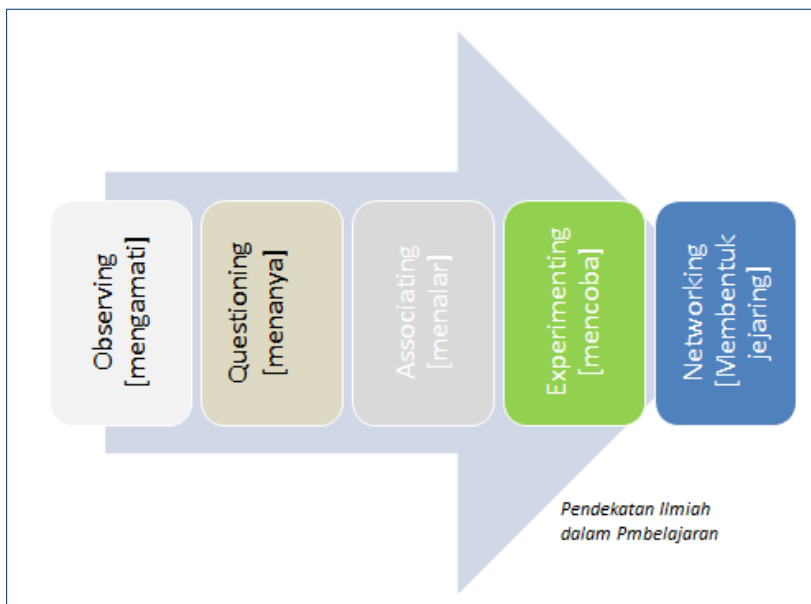

Gambar 1. Alur pendekatan Scientific Aproach

Proses pembelajaran untuk semua jenjang dilaksanakan dengan menggunakan pendekatan ilmiah. Proses pembelajaran harus menyentuh tiga ranah, yaitu sikap, pengetahuan, dan keterampilan. Dalam proses pembelajaran berbasis pendekatan ilmiah, ranah sikap menggamit transformasi substansi atau materi ajar agar peserta didik tahu tentang 'mengapa'. Ranah keterampilan menggamit transformasi substansi atau materi ajar agar peserta didik tahu tentang 'bagaimana'. Ranah pengetahuan menggamit transformasi substansi atau materi ajar agar peserta didik tahu tentang 'apa'. Hasil akhirnya adalah peningkatan dan keseimbangan antara kemampuan untuk menjadi manusia yang baik(soft skills) dan manusia yang memiliki kecakapan dan pengetahuan untuk hidup secara layak(hard skills) dari peserta didik yang meliputi aspek kompetensi sikap, keterampilan, dan pengetahuan.

Pendekatan ilmiah (scientific approach) dalam pembelajaran semua mata pelajaran meliputi menggali informasi melalui pengamatan, bertanya, percobaan, kemudian mengolah data atau informasi, menyajikan data atau informasi, dilanjutkan dengan menganalisis, menalar, kemudian menyimpulkan, dan mencipta. Untuk mata pelajaran, materi, atau situasi tertentu, sangat mungkin pendekatan ilmiah ini tidak selalu tepat diaplikasikan secara prosedural. Pada kondisi seperti ini, tentu saja proses pembelajaran harus tetap menerapkan nilai-nilai atau sifat-sifat ilmiah dan menghindari nilai-nilai atau sifat-sifat nonilmiah.

\section{III.METODE PENELITIAN}

\subsection{Jenis Penelitian}

Sesuai dengan tujuan penelitian ini yakni untuk menghasilkan dan mengetahui efektivitas model yang di integrasikan dan di terapkan berbasis proyek".mengembangan, maka penelitian ini menggunakan pendekatan penelitian pengembangan, dengan menganut model pengembangan Four-D Model yang dikemukakan oleh Thiagarajaan, Semmel, dan Semmel

\subsection{Desain Penelitian}

Metode yang digunakan dalam penelitian ini adalah studi kasus dan desain penelitian eksperimen yang digolongkan pada penelitian praeksperimen dengan rancangan One Group Pretest-Posttest dengan jumlah populasi 48 mahasiswa.

\subsection{Teknik Analisis Data}

a. Analisis Penilaian Proyek Penyelidikan Ilmiah Mahasiswa proyek penyelidikan ilmiah adalah deskriptif kwantitatif yaitu dengan menskor masing-masing aspek tersebut. Hasil penskoran dideskripsikan sebagai berikut.

$$
\begin{array}{r}
1,0 \leq T P M \leq 1,5: \text { berarti" sangat kurang" } \\
1,6 \leq T P M \leq 2,5: \text { berarti" kurang" } \\
2,6 \leq T P M \leq 3,5: \text { berarti" baik" } \\
3,6 \leq T P M \leq 4,0: \text { berarti" sangat baik" }
\end{array}
$$

b. Analisis Tes Hasil Belajar (THB)

$P_{\text {individual }}=\left(\frac{\text { Jumlah skorr yang diperoleh mahasiswa }}{\text { Skor maksimum }}\right) x 100$

c. Ketuntasan klasikal adalah skala presentase $P_{\text {klasikal }} \leq 70$.

$$
P_{\text {klasikal }}=\left(\frac{\text { jumlah mahasiswa yang tuntas }}{\text { jumlah seluruh mahasiswa }}\right) \times 100
$$


d. ketuntasan indikator hasil belajar tiap mahasiswa adalah deskriptif kwantitatif

$$
K=\frac{T}{T 1} x 100
$$

\section{HASIL DAN PEMBAHASAN}

Berdasarkan hasil pembelajaran yang telah diterapkan pada penelitian ini, maka pada rumusan masalah ke satum yaitu keterlaksanaan pengajaran dapat disajikan sebagai berikut:

Berdasarkan hasil pengamatan yang diperoleh dari pada penelitian ini, menunjukkan bahwa waktu yang tersedia digunakan guru untuk memotivasi mahasiswa/memusatkan perhatian mahasiswa dan menyampaikan tujuan pembelajaran $10,37 \%$, mengajukan pertanyaan kepada mahasiswa $8,15 \%$, membagi mahasiswa menjadi beberapa kelompok 5,93\%, meminta mahasiswa mendiskusikan jawaban pertanyaan dalam kelompok 9,63\%, meminta mahasiswa mencari pengertian ilmiah 9,63\%, membagikan LKM 5,93\%, membimbingan mahasiswa melakukan percobaan dan mendiskusikan hasil percobaan 27,41\%, membimbing mahasiswa menerapkan gagasan berdasarkan hasil percobaan 14,07\%, dan memberikan umpan balik untuk membandingkan konsep ilmiah dengan konsep awal $8,89 \%$. Data ini menunjukkan bahwa sebagian besar waktu dalam kegiatan pembelajaran digunakan guru untuk membimbing mahasiswa melakukan kegiatan percobaan dan menerapkan gagasan berdasarkan hasil percobaan yang dilakukan mahasiswa. Adapun data tersebut dapat digambarkan seperti gambar 2 di bawah ini.

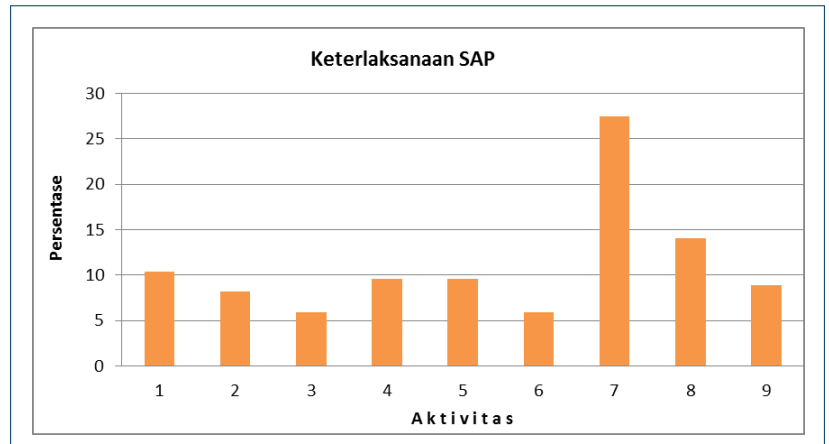

Gambar 2. Rata-rata Skor Keterlaksanaan SAP

Sementara pada rumusan masalah ke dua, yaitu keterampilan memahami mahasiswa dalam penyelidikan autentik. Berdasarkan hasil pembelajaran yang telah diterapkan pada penelitian ini, disajikan sebagai berikut:
Dalam penelitian ini aspek-aspek keterampilan proses yang telah diajarkan kepada mahasiswa kemudian diterapkan dalam melakukan suatu penyelidikan ilmiah. Penilaian terhadap kegiatan mahasiswa selama melakukan penyelidikan ilmiah dilakukan dengan menggunakan instrumen penilaian penyelidikan ilmiah yang terdiri dari penilaian perencanaan, penilaian perancangan, penilaian eksperimen pengumpulan data, penilaian seminar hasil penyelidikan, dan penilaian pelaporan tertulis.

1) Perencanaan

Hasil penilaian terhadap aspek-aspek perencanaan yang dilakukan mahasiswa pada saat perencanaan penyelidikan ilmiah mahasiswa dapat dilihat pada gambar 3 dibawah ini.

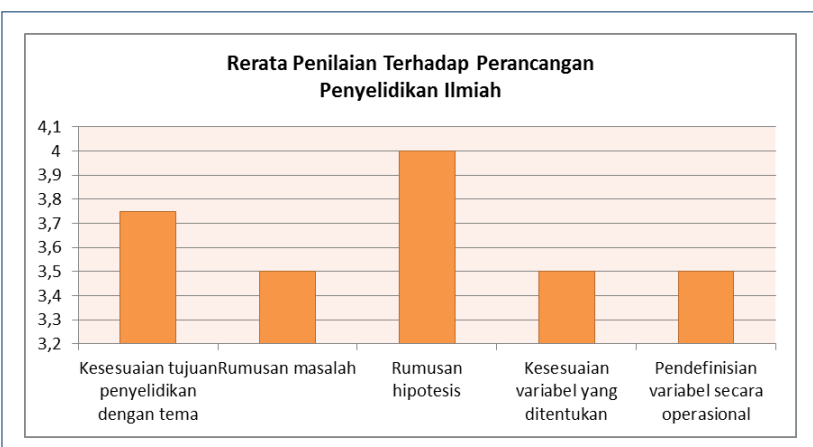

Gambar 3. Rata-rata Skor Penilaian Kegiatan Perencanaan Penyelidikan Ilmiah Mahasiswa

Setelah melakukan kegiatan perencanaan, dilanjutkan dengan kegiatan perancangan.

2) Perancangan

Adapun hasil analisis terhadap aspek-aspek yang dinilai selama proses perancangan yang dilakukan mahasiswa dapat disajikan pada gambar 4 di bawah ini.

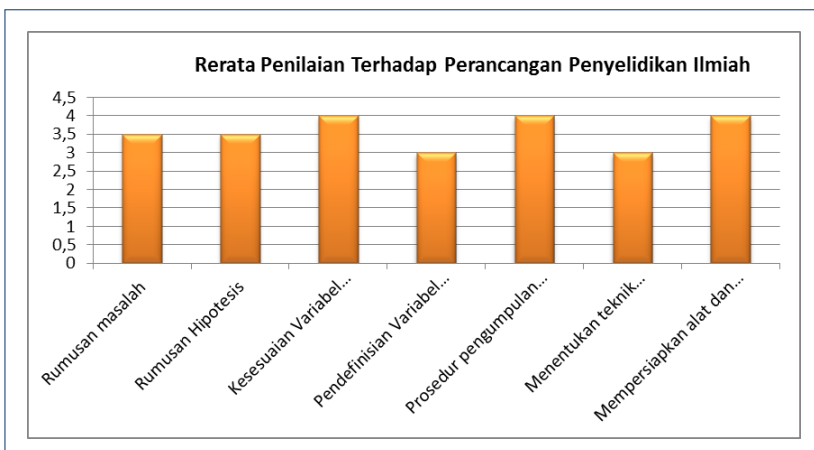

Gambar 4. Rata-rata Skor Penelitian Kegiatan Perancangan Penyelidikan Ilmiah Mahasiswa 
Kegiatan yang dilakukan setelah perancangan adalah pelaksanaan atau eksperimen pengumpulan data.

3) Penilaian pelaksanaan eksperimen

Aspek-aspek yang dinilai selama mahasiswa melakukan eksperimen pengumpulan data pada tahapan pelaksanaan dapat disajian pada gambar 5 di bawah ini.

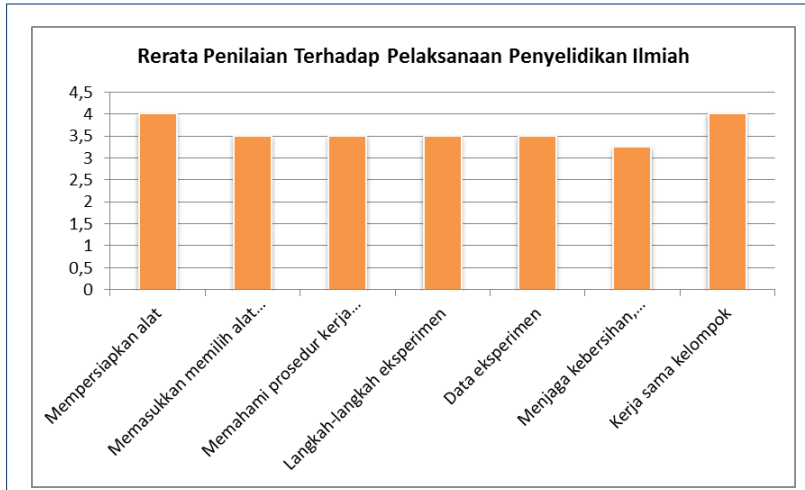

Gambar 5. Rata-rata Skor Penilaian Pelaksanaan Kegiatan Eksperimen Pengumpulan Data Penyelidikan Ilmiah Mahasiswa

Setelah melaksanakan kegiatan eksperimen pengumpulan data, mahasiswa membuat laporan penyelidikan ilmiah yang dilakukan secara tertulis.

4) Pelaporan

Adapun hasil analisis terhadap aspek-aspek yang dinilai dalam laporan penyelidikan ilmiah yang dilakukan secara tertulis oleh mahasiswa pada penelitian ini disajikan pada gambar 6 di bawah ini.

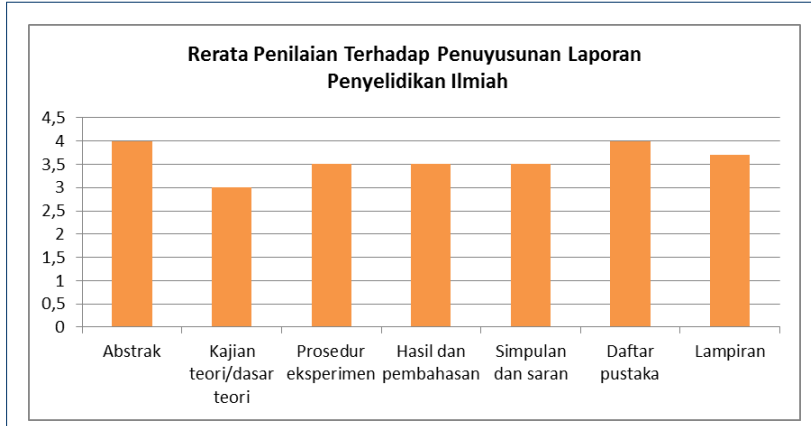

Gambar 6. Rata-rata Skor Penilaian Laporan Penyelidikan Ilmiah Mahasiswa

Setelah laporan penyelidikan ilmiah mahasiswa terkumpul, maka kegiatan berikutnya adalah seminar hasil penyelidikan ilmiah.

5) Seminar Hasil

Adapun hasil analisis terhadap aspek-aspek yang dinilai selama mahasiswa melakukan seminar hasil penyelidikan dapat digambarkan pada gambar 7 di bawah ini.

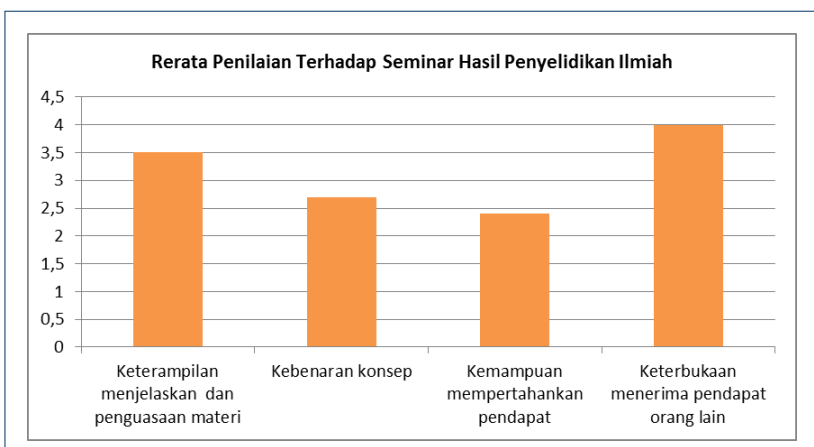

Gambar 7. Rata-rata Skor Penilaian Seminar Hasil Penyelidikan Ilmiah

Analisis terhadap aspek-aspek yang diniali selama mahasiswa melakukan perencanaan, perancangan, pelaksanaan, pelaporan tertulis, dan seminar hasil penyelidikan ilmiah pada penelitian ini lebih rinci terdapat pada Lampiran.

Pada penelitian ini telah menghasilkan perangkat pembelajaran Scientific Aproach sebagai upaya peningkatan kompetensi ilmiah mahasiswa pada program studi fisika UPR, yang dinyatakan layak dari segi validitas, maupun efektivitas penerapannya. Maka berdasarkan kelayakan hal tersebut, pada penerapannya perangkat tersebut hasilnya di bahas pada sub bab berikut.

A. Efektivitas Penerapan Metode Scientific Aproach Berbantukan Model Pembelajaran Berbasis Proyek (PBP)

Pembahasan efektivitas penerapan perangkat pembelajaran yang dikembangkan berdasarkan pada data hasil implementasi instrumen pada penelitian ini adalah sebagai berikut.

1. Penguasaan Keterampilan Proses Mahasiswa

Penguasaan keterampilan proses mahasiswa selama implementasi perangkat pembelajaran yang dikembangkan, diukur dengan menggunakan dua instrumen. Hasil dari masing-masing instrumen tersebut adalah sebagai berikut.

a. Lembar Penilaian Penyelidikan Ilmiah

Aspek-aspek dalam penyelidikan serta keterampilan proses yang telah diajarkan kepada mahasiswa dengan model pembelajaran langsung dan pendekatan keterampilan proses kemudian diterapkan untuk memecahkan masalah dalam kehidupan sehari-hari melalui penyelidikan ilmiah. Masalah yang dijadikan sebagai penyelidikan ilmiah ditentukan sesuai dengan tema umum penyelidikan ilmiah yang diterapkan oleh dosen. 
Dalam mengerjakan penyelidikan ilmiah, mahasiswa diarahkan untuk berkolaborasi dalam kelompoknya masing-masing. Berdasarkan hasil analisis data penelitian ini pada lima tahap dalam penyelidikan ilmiah, rata-rata skor untuk aspek-aspek keterampilan proses yang diniali jauh lebih tinggi dibandingkan dengan rata-rata skor mahasiswa secara individual pada THB proses. Hasil penelitian ini sejalan dengan yang diungkapkan oleh Santyasa (2006: 6), bahwa pembelajaran berbasis yang bersifat kolaboratif dapat menyediakan peluang untuk menuju pada kesuksesan praktek-praktek pembelajaran dimana melibatkan partisipasi aktif para siswa dan juga berdampak pada berkurangnya perbedaan-perbedaan antara individu.

Proses penilaian terhadap perencanaan, perancangan, pelaksanaan, dan pelaporan yang dilakukan dosen selama mahasiswa melakukan penyelidikan ilmiah menunjukkan bahwa pembelajaran berbasis menekankan pada aspek sosial pembelajaran seperti yang diungkapkan oleh Vygotsky. Dimana Vigotsky menekankan bahwa mahasiswa belajar melalui interaksi dengan orang dewasa dan teman sebaya yang lebih mampu dengan tujuan untuk mencapai level of potential development (tingkat perkembangan intelektual yang dicapai individu dengan bantuan orang lain) melalui pemagangan kognitif fan scaffolding (Nur, 2008: 22).

Pada penelitian ini rata-rata skor minimal yang diperoleh mahasiswa selama melakukan penyelidikan ilmiah baik pada saat perencanaan, perancangan, pelaksanaan, maupun pada saat pelaporan adalah 3 dengan kategori baik. Hal ini menunjukkan bahwa mahasiswa telah melakukan setiap tahapan yang direncanakan dan melakukan evaluassi secara kontinyu untuk melihat kembali apa yang mereka kerjakan sehingga pada akhirnya mampu untuk melaporkan hasil akhir berupa produk yang telah dievaluasi kualitasnya baik secara tertulis maupun secara lisan (Buck Institute of Education: 1999) dalam Khamdi (2008).

Berdasarkan analisis aspek-aspek yang dinilai pada penyelidikan ilmiah dapat dikemukakan bahwa pada tahap penyusunan laporan secara tertulis masih terdapat aspek yang memperoleh rata-rata skor rendah yakni kajian teori/dasar teori, hasil dan pembahasan, simpulan dan saran dimana rata-rata skor dan kategori masing-masing aspek berturut-turut adalah 2,75 (Baik), 2,50 (Kurang Baik), 2,75 (Baik). Hal ini disebabkan karena ketiga aspek tersebut saling mempengaruhi satu sama lain. Ditinjau dari penulisan laporan mahasiswa pada aspek-aspek kajian teori/dasar teori menunjukkan bahwa sebagian besar kelompok mahasiswa belum menyertakan hasil eksperimen sebelumnya yang relevan dengan penyelidikan ilmiah yang dilakukan dan belum terdapat kerangka berfikir dalam membangun argumentasi teoritik bahwa eksperimen yang akan dilaksanakan dapat menyelesaikan permasalahan. Pada hasil dan pembahasan sebagian besar kelompok belum melakuakan analisis data dengan memperhitungkan taraf kesalahan/ketelitian pengukuran, belum menuliskan data sesuai dengan aturan angka penting, serta belum menyajikan data dalam bentuk grafik untuk dijelaskan. Pada simpulan dan saran sebagian besar kelompok belum menyertakan perbandingan antara kesimpulan hasil percobaan dengan literatur/teori dan belum terdapat saran yang sesuai dengan temuan yang dapat digunakan untuk perbaikan eksperimen berikutnya.

Pada seminar hasil penyelidikan ilmiah terdapat dua aspek yang memperoleh skor rata-rata kategori baik. Aspek tersebut saling berhubungan satu sama lain dimana karena selama kelompok mahasiswa mempresentasekan hasil penyelidikan ilmiahnya telah mampu menjawab pertanyaan kelompok lain dengan ide yang sesuai. Meskipun demikian selama mempresentasekan hasil dari penyelidikan ilmiah yang dilakukannya, kelompok mahasiswa memperoleh rata-rata skor tertinggi yakni 4,00 dengan kategori sangat baik pada aspek keterbukaan menerima pendapat orang lain. Hal ini sesuai dengan yang diungkapkan oleh Piaget dalam Nur (2004: 34) yang mengungkapkan bahwa pada tahap operasi formal (pemikiran abstrak), seorang siswa akan memiliki kemampuan untuk menalar situasi-situasi dan kondisi yang belum dialaminya, sehingga ia dapat menerima pendapat orang lain atas dasar argumentasi dan diskusi, kondisi-kondisi yang berubah-ubah yang belum diketahui keberadaanya atau bahkan hal yang diketahuinya bertentangan dengan fakta yang ada. Lebih lanjut diungkapkan oleh Piaget pula bahwa pada tahapan operasi formal siswa tidak terkait dengan pengalaman-pengalaman nyata mereka sendiri sehingga mereka dapat menerapkan logika pada setiap himpunan kondisi tertentu.

Berdasarkan uraian di atas secara garis besar dapat disimpulkan bahwa hasil penilaian selama mahasiswa melakukan penyelidikan ilmiah baik pada penelitian ini mendukung penelitian berupa kajian kepustakaan yang dilkaukan oleh Kamdi (2008) yang mengungkapkan bahwa pembelajaran berbasis mampu untuk meningkatkan motivasi, meningkatkan kemampuan pemecahan masalah, dan meningkatkan kolaborasi.

a. Tes Hasil Belajar (THB) Produk

Menurut kriteria ketuntasan mahasiswa secara individual yang ditetapkan oleh universitas setempat, seorang mahasiswa dikatakan tuntuas apabila 
memperoleh rata-rata skor $\geq 56$ atau C. Berdasarkan hasil analisis data ketuntasan hasil belajar produk secara individual, dapat diungkapkan bahwa pada pre test ketuntasan individual secara klasikal adalah $30 \%$, selanjutnya pada post test ketuntasan individual secara klasikal adalah 90\%. Ketuntasan indikator setiap mahasiswa secara klasikal pada pre test adalah $0 \%$ sedangkan pada post tes $70 \%$. Ketuntasan masing-masing indikator pada pre test adalah $30 \%$ dan pada post test adalah $80 \%$. Hal ini megindikasikan bahwa penerapan perangkat model pembelajaran langsung untuk mengajatkan materi kepada mahasiswa telah meningkatkan ketuntasan hasil belajar mahasiswa secara individual, ketuntasan indikator tiap mahasiswa maupun ketuntasan masing-masing indikator dalam materi dynamic.

Berdasarkan hasil penelitian di atas dapat didiskusikan beberapa hal, sebagai berikut, pertama, setelah penerapan perangkat pembelajaran yang dikembangkan pada penelitian ini ternyata masih terdapat 1 mahasiswa yang tidak tuntas hasil belajarnya secara individual. Hal ini dapat disebabkan karena, kurangnya perhatian dosen kepada sebagian mahasiswa selama fase membimbing pelatihan yang mengakibatkan sebagian mahasiswa terabaikan sehingga kurang memahami apa yang diajarkan. Selain itu dapat pula disebabkan oleh perbedaan setiap mahasiswa dalam kemajuan dan perkembangan berpikir. Hal ini sejalan dengan yang diungkapkan oleh Piaget dalam Nur (2004: 41a) bahwa seluruh anak berkembang melalui urutan yang sama namun mereka memperolehnya dalam kecepatan yang berbeda. Oleh karena itu, dosen harus lebih menggunakan upaya khusus dan bervariasi dalam menata kegiatan-kegiatan kelas untuk individu-individu dan kelompok kecil mahasiswa daripada kelompok klasikal.

Kedua, berdasarkan analisis ketuntasan indikator hasil belajar tiap mahasiswa terdapat 3 orang mahasiswa pada penelitian ini dan 2 oranh mahasiswa yang tidak tuntas indikator hasil belajarnya pada post test. Hal ini kemudian berdampak pada ketuntasan masing-masing indikator. Berdasarkan hasil analisis menunjukkan bahwa terdapat 2 indikator hasil belajar yang secara klasikal tidak tuntas pada penelitian ini. Hal ini dapat disebabkan karena dosen selama proses pembelajaran terkesan untuk mempertimbangkan prinsip ekonomi. Prinsip ekonomi yang dimaksudkan merupakan prinsip yang dikemukakan oleh Jerome Brunner (1962) dalam Kardi (2005) bahwa, dalam menjelaskan dan demonstrasi guru perlu benar-benar mempertimbangkan berapa banyak informasi yang akan diberikan dalam kurun waktu tertentu. Hal ini mendorong untuk memberikan rangkuman singkat tentang ide-ide pokok selama pelajaran. Pertimbangan yang dilakukan dosen dalam memenuhi prinsip ini kemudian menjadikan materi yang tergolong kedalam indikator-indikator tersebut tidak maksimal dipahami oleh mahasiswa.

Berdasarkan uraian di atas dapat disimpulkan bahwa butir soal yang tidak sensitif, masih dapat digunakan untuk menguji pemahaman tentang materi dynamic pada mahasiswa atau subjek uji coba yang berbeda.

\section{b. Tes Hasil Belajar (THB) Proses}

Berdasarkan analisis data pada penelitian ini ketuntasan hasil belajar proses mahasiswa secara individual, pada pre test adalah $10 \%$, sedangkan pada post test adalah 100\%., demikian halnya masing-masing indikator hasil belajar proses yang diujikan pada pre test presentase ketuntasanya secara klasikal adalah $10 \%$ sedangkan pada post test adalah $100 \%$.

Berdasarkan penilaian THB psikomotor, ditemukan bahwa ketuntasan setiap mahasiswa secara individual tidak jauh berbeda ketika melakukan pelaksanaan penyelidikan ilmiah secara kelompok. Oleh karena itu dpat disimpulkan bahwa implementasi perangkat pembelajaran yang dikembankan baik pada penelitian ini dapat meningkatkan hasil belajar psikomotor mahasiswa secara individual.

Berdasarkan hasil analisis data keterlaksanaan SAP pada penelitian di atas menunjukkan bahwa, pengelolaan waktu yang dinilai memiliki rata-rata skor terendah ini dapat diakibatkan karena pada fase ketiga dari model pembelajaran yang dikembangkan yakni menerapkan pengetahuan yang dipresentasekan dalam kegiatan eksperimen dan membimbing mahasiswa melakukan eksperimen dinilai memakan waktu yang cukup banyak. Namun secara garis besar dapat diungkapkan bahwa aspek pengelolaan waktu yang dinilai kurang baik oleh pengamat pada saat penelitian ini mengalami peningkatan.

Dalam fase-fase model pembelajaran langsung terdapat pula pengitegrasian pendekatan keterampilan proses dimana pada fase ke tiga dari model pembelajaran langsung dosen membimbing mahasiswa dalam menerapkan materi yang telah dipresentasekan dalam kegiatan eksperimen berupa merumuskan masalah dan hipotesis, mengidentifikasi variabel dan mendefinisikannya secara operasional, merencanakan alat dan bahan, menyusun urutan langkah kerja untuk melakukan eksperimen, melakukan ekperimen dimana aspek-aspek tersebut tergolong kedalam keterampilan terpadu. Hal ini bertujuan untuk melatih keterampilan-keterampilan dasar dalam bereksperimen sebelum mahasiswa dihadapkan dalam melakukan penyelidikan ilmiah. Skor rata-rata minimal yang diperoleh pada fase-fase tersebut berkategori cukup baik, hal ini mengindikasikan 
bahwa sebelum mahasiswa melakukan peroyek penyelidikan ilmiah mahasiswa tersebut telah diajarkan untuk menguasai keterampilan proses terpadu yang menurut Nur dan Samani (1996: 8) merupakan keterampilan yang diperlukan apabila seorang melakukan eksperimen untuk memecahkan masalah.

Pada penelitian, aktivitas mahasiswa diamati pada pertemuan 1, 2, dan 3. Berdasarkan hasil analisis terhadap aspek aktivitas yang diamati persentase aspek-aspek aktivitass yang paling tinggi adalah pada aktivitas mendengarkan penjelasan dosen yakni $37,53 \%$, selanjutnya aspek membaca bahan ajar untuk pertemuan 1 , dan melakukan percobaan untuk pertemuan 2 dan 3 adalah 28,06\%. Dapat pula diungkapkan bahwa reliabilitas instrumen pengamatan aktivitas mahasiswa pada uji coba adalah minimal $95,70 \%$.

Mengacu pada hasil analisis tersebut dapat dikemukakan bahwa frekuensi aktivitas mahasiswa selama proses perkuliahan berlangsung tergolong tinggi. Hal ini dapat dihubungkan dengan pelaksanaan proses pembelajaran yang baik dan terencana dapat membuat aktivitas-aktivitas siswa untuk tetap berada dalam aktivitas sebenarnya. Hal ini sejalan dengan diungkapkan oleh (Kardi, 2005: 4) bahwa sistem pengelolaan dan lingkungan belajar yang baik dapat mengarahkan kegiatan pembelajaran berlangsung dengan berhasil.

Selama proses pembelajaran berlangsung, aktivitas mahasiswa yang dominan adalah mendengarkan atau memperhatikan penjelasan dosen dan diikuti oleh aktivitas berikutnya yakni berdiskusi antara mahasiswa. Hal ini menunjukkan bahwa penerapan perangkat pembelajaran yang dikembangkan dapat menumbuhkan hubungan timbal balik (resiprositas) antara dosen dan mahasiswa maupun antara sesama mahasiswa. Hasil penelitian tentang aktivitas mahasiswa selama proses pembelajaran mendukung pembahasan Brunner mengenai sisi sosial dari proses pembelajaran, yakani kebutuhan mendalam manusia adalah merespon orang lain untuk bekerja sama guna mencapai tujuan yang mana hal ini disebut resiprositas atau hubungan timbal balik. Lebih lanjut Brunner berpendapat bahwa resiprositas merupakan sumber motivasi yang bisa dimanfaatkan oleh dosen untuk menstimulasi kegiatan belajar.

\section{KESIMPULAN}

Berdasarkan temuan-temuan penelitian di atas, dapat disimpulkan bahwa penerapan pembelajaran pendekatan Scientific Aproach yang terintegrasi dalam model pembelajaran berbasis proyek (PBP) dapat meningkatkan serta mencapai kompetensi ilmiah mahasiswa dari segi aspek merencanakan, merancang, melaksanakan, pelaporan, dan menyeminarkan. Model pembelajaran berbasis proyek yang dikembangkan dikatakan layak dari segi validitas maupun dari segi efektivitas penerapannya guna meningkatkan hasil belajar dan aktivitas ilmiah mahasiswa.

\section{UCAPAN TERIMA KASIH}

Saya ucapkan terimakasih banyak kepada : 1) Dekan, ketua jurusan dan ketua program studi pendidikan fisika universitas palangkaraya yang telah memberikan ijin kepada saya untuk melakukan penelitian ini. 2) Para pakar dan ahli serta rekan sejawat saya dan juga para pengamat yang telah membantu pelaksanaan penelitian ini. 3) Mahasiswa yang menjadi subyek penelitian ini, atas peran sertanya pada tahapan proses penelitian ini. 4) Kementerian Ristek Dikti yang telah mendanai penelitian ini.

\section{Penulis}

Saulim DT. Hutahaean*, Nawir, Theo Jhoni Hartanto Dari :

Program Studi Pendidikan Fisika FKIP Universitas Palangkaraya

Alamat :

JL. Yos Sudarso Kampus UPR, Tanjung Nyaho, Palangkaraya

email : s.dapottua.h@gmail.com

\section{Pustaka}

1. Arends, R.I. 1997. Classrom Management and Instructional. New York: McGraw-Hill, Inc.

2. Arikunto, S. 2006. Prosedur Penelitian. Jakarta: PT Rineka Cipta.

3. Barron, B.J. Schwartz, D.L, Vey, N.J, Moore, A, Petrosino, A, Zech, L, Bransford, J. D, The Cognition and Technology Group at Vanderbilt. 1998. Doing with Understanding: Lessons from Research on Problem- and Project-Based Learning. The Journal of the Learning Science.

4. Carin, A. 1993. Teaching Modern Science $3^{\text {rd }}$ Edition. New york. Macmillan Publishing.

5. Dahar, RW. 1989. Teori-Teori Belajar. Jakarta:Erlangga

6. Khamdi, Waras. 2008. Pembelajaran Berbasis Proyek: Metode Potensial untuk Peningkatan Mutu Pembelajaran, sebuah Makalah seminar

7. Keller, J.M. 1987. Development and Use of The ARCS Metode of Instructional Design. Journal of Instructional Develoment. Florida State University Tallhessec. Vol.10 No.3, PP 2-9

8. Mujis, D dan Reynolds D, 2008. Effective Teaching Teori dan Aplikasi. Yogyakarta: Pustaka Belajar 
9. Nur, M. 2000b. Buku Panduan Keterampilan

Proses; Surabaya. Universitas Negeri Surabaya University Press

10. Nur, M. 2002 :" Keterampilan-keterampilan Proses Sains" (makalah disampaikan pada pelatihan pembelajaran yang berkaitan dengan kurikulum berbasis kompetensi kepada para guru MIPA SMU negeri kab siduarjo, pusat sains dan matematika program pasca sarjana unesa)

11. Sukardi, M. 2008. Evaluasi Pendidikan. Jakarta. Bumi Aksara

12. Thiagarajaan, S, Semmel, D.S, dan Semmel, M.I. 1974. Instructional Development for training teacher of Exceptional Children a Sourcebook. Bloomington: Center for Innovation on teaching the Handicaped.

13. Uno, B. 2008. Metode Pembelajaran. Jakarta: Bumi Aksara

14. VanCleave, J. 1997. Guide to the Best Science Fair Projects. John Wiley \& Sons, Inc 